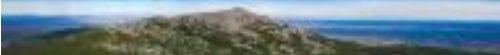

\title{
O RELEVO BRASILEIRO, AS SUPERFÍCIES DE APLANAMENTO E OS NÍVEIS MORFOLÓGICOS ${ }^{1}$
}

\author{
BRAZILIAN RELIEF, PLANATION SURFACES AND MORPHOLOGICAL LEVELS
}

\author{
RELIEF BRÉSILIEN, SURFACES D'APLANISSEMENT ET NIVEAUX \\ MORPHOLOGIQUES
}

\section{JURANDYR LUCIANO SANCHES ROSS ${ }^{2}$}

${ }^{1}$ Professor do Departamento de Geografia da Universidade de São Paulo - USP.

\begin{abstract}
RESUMO
Este artigo sobre relevo, superfícies erosivas e níveis morfológicos é um produto síntese, fruto de pesquisa sistemática e mapeamento desenvolvido nas últimas duas décadas no Brasil e também por meio de pesquisa privada do autor. Seus objetivos são desenvolver uma análise crítica dos mais importantes estudos realizados no Brasil relacionados às superfícies erosivas e, ao mesmo tempo, estabelecer novas interpretações sobre fatos dessa natureza com o auxílio dos conhecimentos adquiridos nos últimos anos. Desta forma, tenta-se mostrar que a interpretação com correlações automáticas entre os níveis morfológicos topográficos e as superfícies erosivas são altamente duvidosos, sendo necessária a adoção de outros parâmetros para as análises. Os exemplares localizam-se nas regiões Sudeste, Centro-Oeste e Minas Gerais, pois podem ser encontradas superfícies niveladas, principalmente ao longo das divisórias das grandes bacias de drenagem do Brasil, ou ainda nas bordas niveladas de bacias sedimentares como Paraná, Parecis e Parnaíba. Além disso, as pesquisas desenvolvidas na Bacia do Alto Paraguai-Cuiabá confirmam um fato que já havia sido observado em outras áreas. Observou-se que naquela região os níveis morfológicos são decorrentes de diversos fatores de caráter estrutural, como superfícies erosivas, idades residuais ou diferenciais, níveis estruturais condicionados, níveis produzidos por erosão diferencial, níveis produzidos por efeito tectônico e níveis produzidos por deposição recente.
\end{abstract}

Palavras-chave: Superfícies de aplanamento; Níveis morfológicos; Relevo brasileiro.

\section{ABSTRACT}

This paper about relief, erosional surfaces and morphologic levels is a synthesis product, yielded through systematic research and mapping developed during the last two decades in Brazil and also trough the author's private research. Its aims are to develop a critical analysis on the most important studies done in Brazil related to erosional surfaces and at the same time, to establish new interpretations about facts of that nature with the help of knowledge brought about during recent years. In this way it tries to show the interpretation with automatic correlations between the topographical morphological levels and the erosional surfaces are highly doubtful, making it necessary to adopt other parameters for analyses. The examples are located in the southeast and Midwest regions and Minas Gerais because there can found levelled surfaces, especially along the divides of the large drainage basins of Brazil, or still in the levelled borders of sedimentary basin such as Paraná, Parecis and Parnaíba. Moreover the research developed in the Basin of High Paraguai-Cuiabá confirms a fact that had already been observed in other areas. It was observed that in that region the morphological levels our because several factors of structural characters, such as erosional surfaces residual or differencial ages, structural conditioned levels, levels produced differential erosion, levels produced by tectonics effect and levels produced by recent deposition.

Key-words: Planation surfaces; morphologic levels; Brazilian relief.

\section{RÉSUMÉ}

Cet article sur le relief, les surfaces érosives et les niveaux morphologiques est un produit de synthèse, produit par la recherche systématique et la cartographie développées au cours des deux dernières décennies au Brésil et également par la recherche privée de l'auteur. Ses objectifs sont de développer une analyse critique sur les études les plus importantes effectuées au Brésil sur les surfaces érosives et en même temps, d'établir de nouvelles interprétations sur des faits de cette nature à l'aide des connaissances acquises ces dernières années. De cette manière, il essaie de montrer que l'interprétation avec des corrélations automatiques entre les niveaux morphologiques topographiques et les surfaces érosionnelles sont hautement douteuses, ce qui rend nécessaire l'adoption d'autres paramètres pour les analyses. Les exemples sont situés dans les régions du sud-est et du mid-ouest et dans le Minas Gerais car il peut y avoir des surfaces nivelées, en particulier le long des divisions des grands bassins versants du Brésil, ou encore dans les limites nivelées du bassin sédimentaire comme Paraná, Parecis et Parnaíba. De plus, les recherches développées dans le bassin du Haut Paraguai-Cuiabá confirment un fait qui avait déjà été observé dans d'autres régions. Il a été observé que dans cette région les niveaux morphologiques sont dus à plusieurs facteurs de caractères structurels, tels que les surfaces d'érosion, les âges résiduels ou différentiels, les niveaux structurels conditionnés, les niveaux produisant une érosion différentielle, les niveaux produits par l'effet tectonique et les niveaux produits par les dépôts récents.

Mots clés: Surfaces d'aplanissement; tage; Niveaux morphologiques; Relief brésilien.

\footnotetext{
${ }^{1}$ Artigo originalmente publicado na Revista do Departamento de Geografia (USP), v. 05, 1991.
} 


\section{1 - INTRODUÇÃO}

Houve uma fase nos estudos geomorfológicos no Brasil em que a análise do relevo passava obrigatoriamente pelo estabelecimento dos chamados níveis de erosão, superfícies de erosão ou ainda superfícies de aplanamento. Os trabalhos quase sempre estavam associados a estudos genéricos desenvolvidos por geógrafos e geólogos, brasileiros ou estrangeiros que, a partir da pesquisa do campo e análise das cartas topográficas e geológicas, estabeleciam interpretações de caráter generalista. Esses trabalhos, com frequência, não faziam parte de um projeto especifico e sistemático de pesquisa, tendo porém quase sempre apoio nas observações de campo. Os produtos cartográficos e gráficos produzidos frequentemente eram esquemáticos e com grande dosagem de imaginação sendo, estes, produtos da análise e não instrumentos para obter-se a interpretação. Foi, entretanto, uma fase importante, pois praticamente marca o início dos estudos geomorfológicos no Brasil. Este momento da história da geomorfologia brasileira praticamente perdura até o final da década de 50. A partir da década de 60 e, principalmente, nas década seguintes, os trabalhos de geomorfologia cada vez mais perdem o caráter generalista, empírico e não-sistemático, para transformarem-se em estudos cujo objeto de pesquisa cada vez mais se torna verticalizado, sistemático e detalhado. Esta nova fase é completamente oposta à anterior. Enquanto a primeira parte do geral para o particular, e tenta adaptar os fatos pontuais à concepção genérica, a fase atual parte dos fatos pontuais e locais e tenta, a partir destes, estabelecer as generalizações. Essa diferença de postura fundamenta-se na metodologia de trabalho, pois enquanto, no primeiro caso, tentavase a realidade aos modelos teóricos, no segundo procura-se descobrir os eventos geomórficos e conjecturar sobre suas possíveis gêneses. Na fase atual, a confecção de gráficos e cartogramas é produto intermediário e, portanto, de apoio fundamental para execução das análises.

O primeiro momento da geomorfologia brasileira esteve sob forte influência do modelo teórico de W. M. Davis. Deste modo, os trabalhos publicados nas décadas de 40 e 50 estão preocupados principalmente com a identificação das superfícies de aplanamento e correlacioná-las com ciclos de erosão de diferentes idades. Os estudos estão fortemente atrelados à interpretação dos estágios de evolução do modelado com uma linguagem davisiana, aparecendo os peneplanos, as peneplanícies, os relevos jovens, os que se encontram na maturidade e os rejuvenescidos. Entre os pesquisadores que se destacam na geomorfologia, nesta fase, estão: De Martonne, Ab’Saber, Almeida, entre outros. Ainda na década de 50, a geomorfologia brasileira sofre influência de Penck através de King. Já nas décadas seguintes, Ab'Saber e Bigarella ampliam os conhecimentos de geomorfologia sob as novas influências da escola de Geomorfologia Climática, mudando-se também a linguagem e, sobretudo, a interpretação dos fatos geomorfológicos. A mudança do modo de interpretar os eventos geomórficos passou a exigir cada vez mais o caminho inverso, o do entendimento do geral a partir dos fatos estudados, local ou pontualmente.

A geomorfologia das duas últimas décadas (70 e 80), embora com pequena produção nacional, não pode mais ser feita a partir da observação genérica dos topos dos morros, de avião ou simplesmente da análise cruzada de cartas topográficas com cartas geológicas. É bem verdade que não se podem dispensar os recursos anteriores, mas também não se pode contentar-se apenas com eles. As pesquisas no campo da geomorfologia são desenvolvidas de forma tão sofisticada quanto as praticadas em pedologia, geologia e outros ramos das Ciências da Terra. Os trabalhos, sejam eles baseados na cartografia geomorfológica, no estudo de processos erosivos superficiais, nos movimentos de massa ou anda relativos à cronoestratigrafia do Quaternário, exigem análises laboratoriais, pesquisas exaustivas de campo e utilização de instrumentos técnico-operacionais cada vez mais sofisticados, quer 
sejam eles ligados aos sensores remotos ou a equipamentos para análise de amostras extraídas da estrutura superficial da paisagem.

Muitas contribuições foram feitas por pesquisadores que o longo do segundo e terceiro quartel deste século [n.e. séc. XX] trabalharam, sobretudo no Brasil de Sudeste, lançando assim as raízes do conhecimento até hoje acumulado no âmbito da geologia e geomorfologia. Cabe, entretanto, ressaltar que alguns estudiosos produziram maior volume de conhecimento e alguns outros com menor volume geraram trabalhos de grande aceitação no meio científico.

No Brasil, de clima tropical, onde o calor e a umidade são variáveis de grande peso a serem consideradas nos processos geomórficos, as dificuldades para encontrar testemunhos confiáveis que comprovem eventos geomórficos pretéritos é enorme. Deste modo, é muito complicado pensar em pesquisas de caráter geomorfológico que não contemplam cada dia mais a importância da erosão química, aquela que se processa no interior do perfil do solo. A meteorização das rochas não pode ser vista como simples fase de mudança de um estado rígido para mais tenro, onde a água passará a agir fisicamente. A alteração dos minerais primários em secundários não é simplesmente uma reação química entre a água que se infiltra no perfil do solo e os minerais que compõem as rochas, mas e também uma ação de desgaste, de modificação das características físicas dos minerais, das rochas e consequentemente do relevo que lentamente vai sendo também esculpido. É um desafio aos estudiosos das diversas disciplinas das Ciências da Terra, entre estes os geomorfólogos, pedólogos, geoquímicos e geólogos, responder à grande pergunta que está em aberto: O que será mais significativo no nível da esculturação das formas do relevo do mundo tropical - a erosão química ou a erosão física, promovidas pela água?

\section{2 - AS SUPERFÍCIES DE EROSÃO: CONTRIBUIÇÕES E CRÍTICAS}

Entre os estudiosos que, de acordo com estágio de conhecimento de suas épocas, deram significativas contribuições estão: De Martonne, Ab’Saber, Almeida, King, Bigarella, entre outros menos divulgados.

O trabalho de De Martonne (1943), denominado "Problemas morfológicos do Brasil tropical úmido", embora apresentando uma titulação que denota a preocupação do autor com a geomorfologia climática da escola europeia, na realidade dá um tratamento à análise do relevo regional bem no estilo das interpretações do modelo davisiano, claramente percebido pela linguagem utilizada e pelos resultados da análise. De Martonne, apesar de ter considerado os efeitos da tectônica que afetou o Leste-Sudeste do Brasil deu grande peso para os níveis morfológicos que identificou como produtos de diversas fases de erosão a que denominou de Superfícies Pré-Permiana; dos Campos; das Cristas Médias; e Neogênica.

A superfície Pré-Permiana, considerada por ele como superfície de erosão fossilizada, corresponde a um plano inclinado que mergulha sob os sedimentos carboníferos e permianos da Bacia do Paraná, na altura dos 550-600 m, e projeta-se para cima, tangenciando os topos das cristas apalacheanas dos terrenos cristalinos, atingindo aproximadamente $1.600 \mathrm{~m}$.

A Superfície dos Campos foi basicamente estabelecida nos topos retilinizados da Serra da Mantiqueira, balizada em torno $1.400-1.500 \mathrm{~m}$, referenciando-se à vegetação de campos naturais de Campos do Jordão, e de Ribeirão Fundo, associada possivelmente ao Cretáceo. Esta superfície, que fora identificada com a ocorrência da vegetação de campos e com o nivelamento dos topos em um trecho da Serra da Mantiqueira, desconsiderou outros níveis morfológicos como, por exemplo, do bloco estrutural da Serra da Bocaina, com topos nivelados acima da cota de $1.700 \mathrm{~m}$, onde se passa, também, a observar a presença da vegetação de campos, conhecidos como Campos da Bocaina. A mesma observação se aplica aos Campos do Maciço de Itatiaia, cuja ocorrência da vegetação de campos encontra-se acima 
de $2.000 \mathrm{~m}$, localizados em um raio não superior a $200 \mathrm{~km}$ de Campos do Jordão. A ocorrência dos campos certamente está associada a problemas climáticos e pedológicos e não obrigatoriamente a superfícies de erosão antiga, muito embora possa ocorrer alguma coincidência.

As Superfícies das Cristas Médias, cujos topos dos morros e serras estabelecem uma superfície plana imaginária, encontra- se entre 1.000-1.100 m e foi datada, por De Martonne, como Paleogênica, ou seja, do Terciário Inferior. Este nível de erosão tangencia os topos das serras como Jaraguá, Japi, Cantareira, entre outras, cujas partes mais elevada encontram-se nas altimetrias acima citadas. Projetando-se para o Centro-Oeste de São Paulo esta superfície tangencia o topo do front da Cuesta de Botucatu - São Carlos onde as altitudes oscilam em torno dos 900-1.000 m. Tal projeção sugere, portanto, que a superfície das Cristas Médias também truncou por erosão os trechos atualmente planos e mais baixos da Bacia do Paraná, cujos testemunhos são encontrados nos limites do Planalto Ocidental Paulista com a faixa escarpada das frentes de cuestas que também delimitam a Depressão Periférica Paulista, a oeste. Esta superfície, na área dos terrenos cristalinos do leste paulista, coincide com os blocos rochosos associados a intrusões de corpos graníticos (serras da Cantareira, do Itapeti, de São Roque, de São Francisco, do Itaqui e parte sul do Japi) ou com blocos estruturais metamórficos rígidos de quartzitos (Jaraguá e parte norte do Japi) e oferece maior resistência aos processos de meteorização e, consequentemente ao desgaste, tanto por ação química quanto física. Estes fatos demonstram que é mais prudente a interpretação através da erosão diferencial, em face da natureza das diferenciações estruturais e litológicas, do que simplesmente níveis ou superfícies de erosão de diferentes idades atreladas diretamente a níveis topográficos ou morfológicos.

A Superfície Neogênica, de De Martonne, é considerada como sendo os terrenos que se nivelaram entre 800-900 m, compreende trechos da Bacia do Vale do Paraíba, do alto Tietê, projetando-se ligeiramente inclinada para oeste, correspondendo ao nível dos topos das colinas da Depressão Periférica. Esta superfície datada, portanto, entre o Terciário Superior e o Quaternário Inferior (Plioceno - Pleistoceno), coincide com o que denominou-se de Superfície de São Paulo por Almeida (1964), que envolve tanto os terrenos cristalinos quanto os sedimentares da Bacia de São Paulo, cujos setores mais altos (800-830 m) nivelaram-se com trechos do Cristalino ligeiramente aplanado dos arredores da cidade de São Paulo. Esta interpretação encontra dificuldade de aplicação para o Médio Vale do Paraíba, cujos níveis topográficos de topo encontram-se entre 650-700 m nos depósitos da Bacia de Taubaté, embora nos terrenos cristalinos imediatamente adjacentes aos sedimentos encontram-se de forma descontínua, morros cujos topos nivelam-se nos $800 \mathrm{~m}$.

À luz dos conhecimentos mais recentes, não se pode mais interpretar os diferentes níveis topográficos-morfológicos do leste paulista automaticamente como sendo diretamente associados às superfícies de erosão. Na realidade, não se pode deixar de lado informações que, de fato, têm interesse na interpretação e análise geomorfológica, como a retilinidade dos topos e a diversidade de níveis morfológicos. Entretanto, enquanto a retilinidade dos topos têm uma explicação na homogeneidade de velocidade de alteração e desgaste erosivo do substrato rochoso e, portanto, do relevo que está esculpido sobre este, os níveis altimétricos diferenciados podem estar associados a diversas gêneses como os efeitos tectogenéticos cenozoicos ocorridos no Leste-Sudeste que soergueram com basculamento de blocos e acabaram por se posicionar em diferentes níveis altimétricos; pelo efeito estrutural das intrusões graníticas e sieníticas que, sob os processos de erosão física e erosão química, apresentam velocidades diferenciadas de desgaste (erosão diferencial) comparadas a outras rochas; pelo efeito estrutural de litologias da família das metamórficas que, em face do arranjo estrutural dos minerais ou da presença maior de um mineral sobre os outros, como 
ocorre no caso dos quartzitos, oferecem maior resistência ao desgaste; ou ainda pelo efeito combinado da tectônica-erosão-deposição que estabelece níveis morfológicos associados a fecho de sedimentação, como ocorre com os vários níveis das colinas das bacias de Taubaté e de São Paulo.

Tomando-se ainda a questão dos níveis ou superfícies de erosão, há que considerar outra variável importante que é a escala de trabalho - o maior ou menor detalhamento da pesquisa geomorfológica. Dependendo da área de pesquisa e da escala de análise, pode-se encontrar uma grande quantidade de superfícies ou níveis morfológicos embutidos uns nos outros e que podem perfeitamente fazer parte da idêntica morfogênese e morfocronologia e não obrigatoriamente de idade e gêneses diferentes. Assim sendo, é preciso estar muito atento às posições topográficas, às localizações em relação aos eixos principais da drenagem, bem como à diversidade litológica, arranjo estrutural destas e efeito da tectônica com o mesmo nível de detalhe do estudo do relevo.

A contribuição de Lester King (1956) com o trabalho "Geomorfologia do Brasil Oriental", após um inventário exaustivo de campo associado à análise da documentação cartográfica e a produtos geológicos, formulou uma interpretação da evolução do relevo brasileiro, associando-o ao do continente africano. A contribuição de King (op. cit.) tem mérito, principalmente pelo fato de introduzir no País uma nova linha de interpretação - a dos policiclos da erosão - e de utilizar na interpretação da gênese das formas de relevo do Brasil o conceito de Pedimentos e Pediplanação, bem como o de introduzir na análise o efeito das fases de soerguimentos generalizados do bloco continental, alternados com fases de erosão pela regressão de escarpas e pedimentação. É a primeira vez que aparece a influência de Penck na interpretação do relevo brasileiro. É bem verdade que o entendimento de que a plataforma ou o bloco subcontinental sofre soerguimento por compensação isostática não é mais possível de aceitação, bem como a obrigatoriedade da alternância soerguimento-erosão. Certamente, a questão dos basculamentos de blocos e os arqueamentos estão associados aos outros fatores que não a isostasia, bem como as fases erosivas que não têm começo nem fim são processos permanentes que podem ter momentos de maior ou menor agressividade em função das mudanças climáticas, de um lado, e dos efeitos da tectônica, de outro.

Toda chave de interpretação do relevo brasileiro elaborada por King (1956) parte de uma constatação por ele feita afirmando que "Elemento fundamental do cenário brasileiro é a vasta planície produzida por denudação entre o Cretáceo Inferior e Terciário Médio, quando foi soerguida e passou a ser dissecada pela erosão policíclica". Essa vasta planície foi denominada de "Superfície Sul-Americana" ou de "Peneplanação Sul-Americana", transformando-se, para King, na chave de entendimento da evolução morfogenética cenozóica do Brasil. Transparece, nesse trabalho, que este foi o único momento que de fato se esculpiu tão vasta superfície plana, cujos resíduos ou testemunhos ainda são encontrados, por exemplo, em trechos da borda da Bacia do Paraná e na Serra do Espinhaço, entre outros.

Enquanto os testemunhos dos ciclos anteriores como o Gondwana (Cretáceo Inferior ao Jurássico) e o Pós-Gondwana (Cretáceo Superior) encontram-se fossilizados pelos depósitos do Cretáceo, os ciclos velhas (Terciário Superior) e Paraguaçu (Pleistoceno) dissecam a superfície Sul-Americana e com isso os seus testemunhos estão embutidos nesta última, que foi mais ampla.

Toda interpretação morfogenética de King (1956) acaba por misturar conceitos associados a Davis e Penck. O modelo de Davis está empregado quando raciocina em relação à "Peneplanação Sul-Americana" - que gerou a vasta e acabada planície Sul-Americana, concepção finalista de Davis. Mas, ao fazer a interpretação de que o relevo do leste do Brasil evoluiu pelas fases ou ciclos de erosão alternados com soerguimentos do bloco subcontinental, por efeito da compensação isostática (perda de peso pelo efeito da 
denudação), aplicou o Conceito de Treppen de A. Penck, utilizado por este último para explicar os diferentes níveis topográficos do Maciço da Floresta Negra, na Alemanha. Já o conceito de Pediplanação, aplicado para a explicação da evolução da regressão das escarpas, é aplicação da concepção de evolução de vertentes de W. Penck por recuo paralelo.

A projeção automática para qualquer parte do Brasil, dos níveis ou ciclos de erosão de L. King, é extremamente complicada. Como todo trabalho foi desenvolvido na região serrana e planáltica do Leste- Sudeste, sobretudo nos terrenos da Serra do Espinhaço e entorno, tornam-se impraticáveis as extrapolações generalizantes. Cabe ressaltar, como exemplo, o fato de que King não percebeu a importância dos corredores das depressões circundantes às bacias sedimentares, depressões estas esculpidas a partir das faixas de contato entre os sedimentos e o cristalino, já identificadas e apresentadas por Ab'Saber e Almeida (1949), principalmente para o caso da Bacia do Paraná.

A contribuição de Bigarella, Mousinho e Silva (1965) a respeito da superfície de erosão chegou através de uma tentativa de modelização para interpretação da evolução do relevo brasileiro. Os autores, a partir de estudos efetuados no Sul e Sudeste do Brasil, sobretudo na região da Serra do Mar, através de trabalho publicado com a denominação de "Pediplano, Pedimentos e seus Depósitos Correlativos no Brasil", propõem três grandes fases erosivas ocorridas por Pediplanação. Tal interpretação apoiou-se na influência de King e Penck e passa pela concepção de que as vertentes evoluem por recuo paralelo em ambientes áridos em semiáridos e ao recuarem geram superfícies aplanadas e arrasadas por erosão. Tais superfícies se definem através dos Pedimentos e a coalescência destes define os Pediplanos. Atividade erosiva exercida de um lado implica na deposição dos sedimentos de outro, os chamados depósitos correlativos. Deste modo, fica implícito que a cada fase erosiva deve existir uma correspondência de sedimentação. Os autores identificaram três superfícies de Pediplanação a que denominaram de $\mathrm{Pd}_{1}, \mathrm{Pd}_{2}$ e $\mathrm{Pd}_{3}$, a que devem corresponder três significativos depósitos correlativos, $\mathrm{P}_{1}, \mathrm{P}_{2}$ e $\mathrm{P}_{3}$. Com a preocupação de estabelecer relação entre gênese e idade, propõem para o $\mathrm{Pd}_{3}$, idade no Cretáceo-Eoceno, coincidindo com a sedimentação do Cretáceo por todo o Brasil.

Esta superfície chamada de $\mathrm{Pd}_{3}$ deveria corresponder à Superfície de Cimeira, também chamada, por De Martonne, de Superfície dos Campos e das Cristas Médias. Estas superfícies mostram-se, segundo os autores, deformadas por efeito da tectônica e da dissecação Cenozóica.

A superfície $\mathrm{Pd}_{2}$ teria se processado a partir do Terciário Médio, correspondendo às superfícies interplanálticas periféricas com ciclicidade de fases secas e úmidas. Esta fase grosseiramente corresponde ao ciclo Velhas de King, quanto à idade. A abertura das depressões periféricas que definem corredores depressionários nos contatos do cristalino com sedimentos das bacias do Paraná, Paranaíba e Amazonas, Ab'Sáber denominou de superfície Neogênica.

A superfície $\mathrm{Pd}_{1}$ corresponde às áreas em processo de esculturação definidos morfologicamente através de alvéolos embutidos na superfície Neogênica do Sul e Sudeste, bem como nos tabuleiros litorâneos do Nordeste, que corresponderia ao ciclo Paraguaçu de Lester King.

Aplicação automática da proposta dos autores supracitados encontra dificuldades extremamente grandes. Ao conseguir-se identificar uma determinada superfície que se enquadra no $\mathrm{Pd}_{1}, \mathrm{Pd}_{2}$ ou $\mathrm{Pd}_{3}$ é muito complicado encontrar-se o depósito correlativo correspondente.

Nas tentativas de pesquisas em que se procurou aplicar tal linha teórica, os resultados sempre foram decorrentes de análise conjectural. A dificuldade de encontrarem-se fósseis e qualquer outro tipo de materiais datáveis coloca os resultados da interpretação no condicional. 
Quando a área estudada encontra-se nos terrenos muito dissecados do cristalino do LesteSudeste, as dificuldades ainda se tornam maiores, em face da elevada dissecação do relevo, o elevado estágio de meteorização das rochas e o mascaramento dos perfis dos depósitos pela intensa pedogenização típica dos ambientes quentes e úmidos. Nestes casos, o trabalho somente tem maiores condições de evoluir através do método de análise de solos que só se prestam do Quaternário mais recente. São quase impraticáveis as análises cronoestratigráficas seguras para os depósitos correlativos das superfícies denominadas de $\mathrm{Pd}_{3}$ e $\mathrm{Pd}_{2}$, a não ser pelos métodos clássicos da cronoestratigrafia relativa, amplamente utilizada pela análise geológica e geomorfológica. Esta, entretanto, é conjectural entre fatos de aspectos semelhantes ou não e quase sempre são difíceis de serem encontrados e analisados.

Outras contribuições importantes para o entendimento da evolução do relevo brasileiro foram dadas por Ab'Saber (1949-1960-1972) no âmbito da superfícies de erosão. A identificação, por Ab'Saber, de regiões no Brasil com marcas de circundenudações précretáceas foi a primeira etapa para, posteriormente (1960), estabelecer uma sequência de níveis ou superfícies de erosão, a que Ab’Sáber denominou de "Posição das Superfícies Aplainadas no Planalto Brasileiro". Nesta proposta, identifica quatro níveis ou superfícies de aplainamento, assim denominadas:

- Superfícies de Cumiada ou Cimeira.

- Superfícies Intermontanas, Interplanálticas ou Embutidas.

- Superfícies Fósseis em Exumação.

- Superfícies de Eversão.

Não houve, neste trabalho, a preocupação com a datação das superfícies, mas sim sua identificação e posicionamento ao longo do território brasileiro.

As superfícies de Cumiada ou Cimeira englobam tanto as Superfícies de Campos quanto as Cristas Médias anteriormente identificadas por De Martonne. Para Ab'Sáber, estas superfícies correspondem a antigas áreas de erosão, atualmente posicionadas em níveis elevados (acima de $1.000 \mathrm{~m}$ ) em face dos processos tectogenéticos - arqueamentos devidos à epirogênese pós-cretácea.

As Superfícies Intermontanas, Interplanálticas ou Embutidas correspondem, para Ab'Sáber, às grandes depressões periféricas que circundam as bacias sedimentares como a Depressão Periférica Paulista (Superfície Neogênica de São Paulo), Depressão Central no Rio Grande do Sul e a Depressão Central Sertaneja no Nordeste Brasileiro. Estas depressões teriam sido esculpidas ao longo do Neogeno (Plioceno- Pleistoceno).

As Superfícies Fósseis em Exumação correspondem a antigas superfícies de aplanamento que foram encobertas por sedimentos das grandes bacias sedimentares e que atualmente se encontram em processo de exumação. Estas áreas correspondem às margens das Depressões Periféricas.

As Superfícies de Eversão correspondem, para Ab'Sáber, àquelas áreas que representam superfícies antigas exumadas. Compreendem depressões como a Cuiabana e a Sertaneja, que se encontravam encobertas por sedimentos das bacias sedimentares e que atualmente estão expostas por efeito de fases erosivas mais recentes.

Ab'Saber (1972), em estudos posteriores mais sistematizados, redefine as superfícies aplainadas na participação da compartimentação do Planalto Brasileiro, valorizando a tipologia de depressões em face de uma classificação genética. Assim, surgem as denominações de:

\section{- Depressões Periféricas Subsequentes.}


- Depressões Monolíticas

- Depressões Marginais com forte Eversão.

- Depressões Marginais com Eversão e formação de Bacias Detríticas.

As Depressões Periféricas Subsequentes estão representadas pelas superfícies esculpidas ao longo do Neogeno e Pleistoceno, nas bordas de bacias sedimentares. Estas depressões são caracterizadas ainda por se encontrarem embutidas entre reversos de maciços cristalinos de um lado e escarpas cuestiformes de outro, que acabam por determinar extensos corredores depressionários subsequentes às estruturas das bacias sedimentares. Isto ocorre, por exemplo, com a Depressão Periférica Paulista, Depressão Periférica Sul-Rio-Grandense ou, como é conhecida regionalmente, Depressão Central do Rio Grande do Sul.

As Depressões Monoclinais, conforme a denominação indica, correspondem às depressões embutidas em bordas de bacias sedimentares. Estas depressões, geralmente escavadas por rede hidrográfica cujo eixo principal é de drenagem anaclinal (obsequente), são individualizadas por frentes de Cuestas desdobradas. Estas depressões são encontradas principalmente na borda oeste e noroeste da Bacia do Paraná, destacando-se as do alto rio Taquari (MS) e do rio Vermelho (região de Rondonópolis, MT).

As Depressões Marginais com Forte Eversão assim foram denominadas por margearem bordas de bacias sedimentares, e por se encontrarem esculpidas em rochas antigas de maciços cristalinos ou de rochas metassedimentares antigas.

A denominação de Eversão decorre do fato de estas depressões apresentarem suas superfícies aplanadas por ciclos erosivos muito antigos (Pré-Devoniano) e por terem sido sepultadas pelos depósitos paleomesozoicos das grandes bacias sedimentares e, no Cenozoico Superior, após e durante os eventos epirogenéticos (Terciário), terem sido parcialmente exumados pelos processos erosivos cincundenudacionais. Nestas características genéticas, enquadram-se as depressões Cuiabana (MT), do Miranda (MS), a Sertaneja (Nordeste), do Tocantins (TO) e as do Norte e Sul Amazônicas (PA-MA).

As Depressões Marginais com Eversão e formação de Bacias Detríticas correspondem àquelas cujas gêneses assemelham-se à anteriormente descrita, acrescentando-se a estas a geração de depósitos detríticos Cenozoicos. Entre as que apresentam estes, podem ser lembradas a Depressão do alto Paraguai, com cobertura da Formação Pantanal (Pleistoceno), e a Depressão do Guaporé, com cobertura da Formação Guaporé (Pleistoceno), entre outras de menor expressividade em área.

Nesta interpretação da compartimentação do relevo brasileiro apresentada por Ab'Saber, ele acabou por definir geneticamente as grandes unidades esculturais do relevo do Brasil. Nestes estudos, fica nítida a influência das concepções teóricas de W. Penck e de Lester King em Ab'Saber, ao interpretar a evolução do relevo. Isto transparece claramente na aplicação das ideias do soerguimento de caráter epirogenético desigual (arqueamentos dômicos) e a utilização de conceitos relativos aos processos erosivos por pediplanação (ambientes áridos e semiáridos) alternados com processos erosivos lineares e forte meteorização das rochas (ambientes quentes e úmidos).

Parece-nos que, em nível regional, quem melhor contribuiu para a geomorfologia brasileira foi de fato Ab'Saber, que sistematizou, organizou e acrescentou conhecimentos que podem ser incorporados de forma quase que definitiva na interpretação e análise da gênese do relevo brasileiro. Sintetizando anda um pouco mais, pode-se firmar que, de fato, a compartimentação do relevo no território brasileiro torna-se mais facilmente compreensível quando se utiliza dos conceitos de Morfoestrutura e Morfoescultura (efeitos dos processos endógenos e exógenos) de Gerassimov \& Mescerjakov (1968). 
No âmbito das morfoestruturas (formas de relevo comandadas pela estrutura), têm-se as grandes formas determinadas pelas estruturas cristalinas antigas (crátons ou plataformas), os cinturões orogênicos ou geossinclíneos (dobramentos ou orogenia antiga) e as bacias sedimentares (paleomesozóicas).

São nestas grandes morfoestruturas que os processos exógenos (ação climática) atuam e atuaram no passado, resultando em morfoesculturas de gêneses complexas. Entretanto, além da complexidade morfológica gerada, de um lado, pelas variações climáticas pretéritas e, por outro, pela complexidade litoestrutural, há um grande divisor na história da evolução do relevo brasileiro - a epirogenia ou soerguimento generalizado, porém desigual da plataforma sul- americana. Se o processo de soerguimento que parece ter iniciado no Pós-Cretáceo (Terciário) foi contínuo ou intermitente, ainda é difícil de afirmar; entretanto, é indiscutível sua ocorrência. Deste modo, o que se tem, em nível de compartimentação do relevo no Brasil, são, de fato, as influências passivas da litoestrutura (morfoestruturas), das influências ativas da tectônica (epirogenia - soerguimento, falhas, intrusões) influências ativas dos processos exógenos (variações climáticas no tempo e no espaço).

As influências climáticas antigas (Pré-Cenozóicas), que resultaram em processos erosivos extensivos e deixaram marcas indeléveis nas formas particularmente grandes do relevo, ainda podem ser testemunhadas por resíduos de antigas superfícies de aplanamento deixadas em morfoestrutura antigas como nas áreas Cratônicas ou de plataformas e nos níveis topográficos elevados dos Geossinclíneos ou nos cinturões orogênicos. Deste modo, os testemunhos de superfícies de erosão ou aplanamento antigas (Pré-Cenozóicas) aparecem nos diversos níveis de superfícies retinilizadas, nivelados e até mesmo aplanados, nas áreas elevadas dos Geossinclíneos do Atlântico (Serra do Espinhaço, Serra da Mantiqueira, reverso da Serra do Mar), no Geossinclíneo Brasília (Serra Dourada, Serra das Caldas Novas, Serra da Mesa, Chapada de Brasília, Chapada dos Veadeiros, em Goiás), no Geossinclíneo Paraguai Araguaia nos topos planos ou ainda retilinizados da Província Serrana (Serra Azul, Serra das Araras, Serra da Água Limpa, Serra da Poção Sabão, Serra da Bodoquena, MT e MS) e na Plataforma Amazônica (depressões Marginal Norte-Amazônica e Marginal Sul-Amazônica) e em trechos baixos e arrasados nas áreas do Geossinclíneo Paraguai-Araguaia (depressões Cuibana e do Miranda), do Geossinclíneo do Atlântico (Depressão Sertaneja), estas últimas correspondendo às Superfícies de Eversão definidas por Ab'Saber (op. cit.).

As marcas das atividades erosivas Cenozóicas, sobretudo as do Cenozoico Superior (Plioceno - Pleistoceno), são testemunhadas pelos corredores de Depressões circundantes às bacias sedimentares, quer sejam elas periféricas, monoclinais ou marginais. Ressalta-se mais uma vez que as Depressões Marginais, conforme Ab'Sáber (1972), foram abertas no Neogeno e Pleistoceno, como as demais; entretanto, ao serem esculpidos, exumaram antigas superfícies (Pré-Devonianas) que se encontravam sepultadas pelos sedimentos das grandes bacias sedimentares Fanerozóicas.

A proposta de classificação do relevo de Ross (1989) deixa bastante clara a macrocompartimentação do relevo brasileiro sob a influência dos efeitos esculturais, de um lado, e estruturais de outro. Sob a égide dos conceitos de Morfoestrutura e Morfoescultura, que em última análise é a influência de W. Penk (processos endógenos e exógenos), Ross (op. cit.) propõe a divisão do relevo do Brasil em Unidades Morfoesculturais (incorporando o morfoestrutural), assim definidos:

\section{- Planaltos em - Bacias Sedimentares \\ - Cinturões Orogênicos \\ - Núcleos Cristalinos Arqueados}

- Depressões Marginais e Periféricas 
- Planícies Fluviais e Marinhas

Esta classificação, que trata especialmente dos níveis de erosão, procura valorizar a gênese como fator de definição das formas de relevo. Deste modo, estrutura, tectônica e esculturação são ingredientes indispensáveis para a interpretação geomorfológica e não tãosomente fases de erosão.

\section{3 - A DIVERSIDADE GENÉTICA DOS NÍVEIS MORFOLÓGICOS OU TOPOGRÁFICOS}

Diante do que foi exposto no item anterior, fica evidente que não se pode estabelecer uma relação direta e absoluta entre as Superfícies de Aplanamento, os diferentes níveis morfológicos ou topográficos e as idades das formas. Embora se possa estabelecer algumas generalizações de âmbito regional, admitindo-se que os níveis aplanados ou pelo menos retinilizados, dos topos dos geossinclíneos, sejam testemunhos de fases erosivas antigas (PréCenozoico) e que as depressões e superfícies embutidas e de bordas das grandes bacias sedimentares sejam de idade mais recentes (Terciário Superior e Quaternário), quando se aumenta a escala de estudo é preciso tomar cuidado para avaliar o que se enquadra no contexto geral e o que é particularmente da área em estudo.

Os níveis morfológicos ou topográficos, locais ou regionais, podem estar associados a diversas origens, e, portanto suas existências associam-se a gêneses diversas. Entre as gêneses dos níveis morfológicos, podem-se destacar os seguintes:

- Extensos níveis planos ou de topos retilíneos nivelados, que testemunham superfícies de erosão antiga.

- Superfícies de topos retilinizados em níveis diferenciados por blocos basculhados por efeito da tectônica.

- Superfícies com topos retilinizados em níveis diferenciados, esculpidos em estruturas cristalinas e/ou cristalofilianas, por efeito da meteorização/erosão diferencial.

- Níveis em patamares com superfícies planas ou aplanadas em estruturas sedimentares com litologias tenras alternadas com rígidas.

- Níveis em patamares escalonados com superfícies planas ou em rampas de pouca declividade, condicionadas pelo acamamento de diversas fases de derrames de lavas.

- Superfícies aplanadas antigas, sepultadas por pacote sedimentar e posteriormente exumadas, marginais às bordas de bacias sedimentares.

- Superfícies aplanadas por processos erosivos generalizados - superfícies de erosão ou aplanamento, embutidas em bordas de bacias sedimentares e maciços antigos.

- Superfícies planas de topos posicionadas em reverso de escarpa de bordas de bacias sedimentares.

- Níveis diferenciados de topos de ocorrência local associados a corpos intrusivos ou vulcânicos.

- Níveis diferenciados associados a fases de deposição/erosão recentes em depressões tectônicas.

- Níveis diferenciados associados a fases de deposição/erosão Quaternárias de ambientes de sedimentação fluvial, marinha ou lacustre.

- Os extensos níveis planos ou de topos retilíneos nivelados que testemunham superfícies de erosões antigas correspondem a trechos altos localizados na área dos cinturões orogênicos antigos. Deste modo, estas superfícies residuais são encontradas na Serra do 
Espinhaço em Minas Gerais e Bahia, na Chapada de Brasília, na Chapada dos Veadeiros, e nos topos planos das serras da Mesa, Dourada e Caldas Novas em Goiás, Canastra, e Negra em Minas Gerais. Estas superfícies de erosões antigas que atuaram nas estruturas dobradas e em intrusões do Geossinclíneo Paraguai-Araguaia. Neste observa-se, também, superfícies altas e de topos planos ou cristas retilinizadas na área da Província Serrana em Mato Grosso. Estas superfícies relictuais não se encontram obrigatoriamente nos mesmos níveis altimétricos. As altimetrias dos topos oscilam entre os 600-800 m na Província Serrana, e 1.200-1.400 m no Geossinclíneo Brasília e na Serra do Espinhaço, sendo que em pequenos trechos os níveis ultrapassam os $1.600 \mathrm{~m}$. Cabe ressaltar, entretanto, que os testemunhos de aplanamento de processos erosivos Pré-Cenozoicos encontram-se preferencialmente nos grandes divisores de águas das bacias do Paraná-Amazonas (Província Serrana), do Tocantins - São Francisco - Paraná (Serras de Goiás e oeste de Minas Gerais) e São Francisco - Doce e Jequitinhonha (Serra do Espinhaço). As superfícies identificadas na Serra do Espinhaço foram datadas por King (1956) como Pré-Cretáceas e Cretáceas (Gondwana e Pós-Gondwana) enquanto níveis pouco mais baixos do Geossinclíneo do Atlântico como Superfície Sul-Americana no Terciário Inferior. Admitindo-se como correto que a reativação Wealdeniana (ALMEIDA, 1967) ou a epirogênese Pós-Cretácea (AB'SABER, 1969) tenha se iniciado no Jura-Cretáceo e se estendido até o Terciário Médio, torna-se mais difícil aceitar que os testemunhos de superfícies de aplanamento dos topos das serras e chapadas dos Geossinclíneos sejam do Terciário Inferior ou Paleogeno, devendo ser muito mais provavelmente do Pré-Cenozoico.

- As superfícies de topos retilinizados com níveis diferenciados por blocos basculados por efeito da tectônica podem ocorrer nas mais diversas áreas do Brasil, principalmente naquelas onde a atuação da tectônica quebrante Cenozóica foi mais marcante. Bons exemplos deste tipo de evento podem ser encontrados no Sudeste do Brasil, sobretudo nas áreas conhecidas na literatura como Serra do Mar e Serra da Mantiqueira. São fatos amplamente estudados e divulgados, por especialistas, os efeitos da tectônica Cenozóica no soerguimento, na reativação de falhas antigas e no basculamento de extensos blocos que promoveram o aparecimento das escarpas da Serra do Mar e da Serra da Mantiqueira. Estes efeitos tectônicos, contemporâneos ao Geossinclíneo Andino, geraram no Sudeste brasileiro diferentes níveis em degraus de topos retilinizados tanto na faixa litorânea da escarpa da Serra do Mar (escarpas e morros litorâneos isolados) como na Serra da Mantiqueira ou ainda na Serra da Bocaina, nos estados de São Paulo e Rio de Janeiro. Os diferentes níveis estão balizados nos 250-300 m (morros litorâneos), 800-900 m (topo da Serra do Mar), 1.400-1.600 m (Serra da Mantiqueira e Bocaina) e não correspondem obrigatoriamente a diferentes fases erosivas e sim a efeitos tectogenéticos. Deve-se, portanto, tomar precauções quando se estabelece as datações dos níveis altimétricos do Geossinclíneo Atlântico, especialmente na faixa litorânea sudeste onde as deformações tectônicas cenozóicas colocaram testemunhos de idêntica superfície de erosão Pré-Cenozóica em vários níveis altimétricos, que não podem ser interpretados como superfícies de erosão ou aplanamento distintos e de diferentes idades. Deste modo, as datações das Superfícies de Campos, de Cimeira, das Cristas Médias e a Superfície de São Paulo podem perfeitamente pertencer à mesma fase erosiva e, portanto, à mesma idade, e que a tectônica ao longo do Terciário Inferior incumbiu-se de deformá-la.

- As superfícies com topos retilinizados, posicionados em níveis diferenciados e esculpidos em estruturas cristalinas e cristalofilianas e geradas por efeito da erosão diferencial, também são frequentes no Leste e Sudeste do Brasil ao longo do Geossinclíneo do Atlântico. A presença de complexos litológico-estruturais nas faixas de dobramentos apresentam rochas de diferentes idades, graus de metamorfismos, arranjos estruturais e presença maior ou menor de determinados componentes minerais. Associados a isto, ainda 
ocorrem as falhas, fraturas, planos de xistosidade (bandeamentos), rochas intrusivas de diferentes naturezas minerais, tudo contribuindo para facilitar ou dificultar a ação da água nos processos de meteorização das rochas e transporte dos minerais alterados. Deste modo, as áreas que se apresentam com as rochas muito afetadas por falhas, fraturas, ou que apresentam planos de xistosidade bem marcados (bandeamento) ou, ainda, rochas com maior presença de minerais mais susceptíveis à ação química da água (biotita, muscovita, feldspatos) nos ambientes tropicais úmidos mostram-se mais facilmente atacáveis pela meteorização e, consequentemente, pela erosão química e física promovidas pela água. Nas áreas adjacentes que tenham a presença de rochas com menor ocorrência de fraturas, bandeamentos ou mesmo que, em face dos processos de gênese como, por exemplo, grau de metamorfismo maior ou grande homogeneidade mineralógica ou, ainda, maior presença de minerais resistentes à ação química da água (quartzos), a velocidade de meteorização e o transporte por erosão química e física da água são retardados. Com isto, estas áreas tendem a sobressair-se na paisagem, detendo níveis altimétricos mais elevados. No Brasil, com clima quente e úmido, o que frequentemente se observa, principalmente nas faixas dos Geossinclíneos do Atlântico, Brasília e Paraguai-Araguaia é a presença de níveis de topos diferenciados em formas de cristas monoclinais ou de patamares estruturais escalonados, sustentados por quartzitos ou até mesmo arenitos silicificados, ao lado de relevos pouco mais baixos, esculpidos em gnaisses, migmatitos, micaxistos, calcários etc. São também frequentes nestas circunstâncias as intrusões graníticas, sieníticas ou de rochas básicas, que devido a sua maior homogeneidade mineralógica, presença de minerais mais resistentes à ação química da água e à menor presença de linhas de fraqueza (fraturas, diaclasses), também oferece maior resistência ao desgaste e, consequentemente, sobressaem-se como relevos topograficamente mais elevados. Esta diferença de velocidade de esculturação é o que se denomina de erosão diferencial, tendo alguns bons exemplos nos arredores de São Paulo, como o Pico do Jaraguá, Serra do Itapeti, Serra da Cantareira, entre inúmeros outros.

- Os níveis diferenciados de topo de ocorrência local associados a corpos intrusivos ou vulcânicos, embora já tenham sido parcialmente tratados anteriormente, merecem ainda algum destaque. No território brasileiro, a presença dos corpos intrusivos de diferentes idades e gêneses são abundantes, tanto nas áreas dos Geossinclíneos como nas áreas das plataformas ou crátons. Corpos intrusivos de granitos, sienitos, diabásios, gabros entre outros, são frequentemente responsáveis pela sustentação de relevos mais elevados em áreas restritas, sendo que raramente determinam extensas superfícies elevadas contínuas. Tais corpos intrusivos emergem na superfície pela denudação regional e acabam por se destacar topograficamente por efeito de erosão diferencial. Deste modo, áreas como Maciço do Itatiaia, Serra de Poços de Caldas e Ilha de São Sebastião, entre inúmeras outras, são produtos desta gênese, não podendo, portanto, serem confundidas simplesmente como testemunhos de pretéritas superfícies de erosão ou aplanamento.

- Os níveis em patamares com superfícies planas ou aplanadas, esculpidos em estruturas sedimentares com alternância de litologias tenras e rígidas, são encontrados basicamente em bordas de bacias sedimentares esculpidas por processos erosivos circundenudacionais ou, ainda, nas áreas interiorizadas das bacias posicionadas ao longo dos divisores d'água. Estes patamares são encontrados nas escarpas produzidas pelo recuo erosivo tanto nas bordas de bacias quanto nos morros, testemunhos comumente encontrados nas proximidades ou ao longo dos interflúvios interiorizados.

Estes tipos de ocorrência são frequentes nas bacias sedimentares do Paraná, do Parnaíba, Amazônica, Chapada dos Parecis em Mato Grosso e Rondônia e na Chapada da Serra do Divisor ou Urucuia entre Goiás e Bahia. Estes patamares são devido a diferença de resistência que rochas como arenito, argilitos, calcários, siltitos, entre outros, oferecem ao 
desgaste, seja por erosão regressiva em cabeceiras de drenagem ou recuo paralelo de vertentes.

- Níveis em patamares escalonados, com superfícies planas ou em rampas geralmente de pouca declividade, condicionadas pelas diversas fases de derrames de lavas. Estes níveis são caracterizados pelo arranjo estrutural das diversas camadas de basalto e diabásio ou, ainda, de riolitos e riodacitos, principalmente na Bacia do Paraná. As camadas rígidas dos derrames de lavas nas áreas mais ao norte desta bacia são responsáveis pela sustentação de escarpas que definem relevos de tipo Cuesta (ALMEIDA, 1949). As vertentes escarpadas são encontradas preferencialmente nas bordas das bacias na transição dos terrenos planálticos para as depressões periféricas na borda oriental e monoclinais na borda ocidental. Mais ao sul, as vertentes escarpadas assumem aspecto bem mais diferenciado, em face da maior incisão dos vales fluviais e da maior exposição dos derrames aos efeitos da denudação. (O condicionamento estrutural dos acamamentos dos derrames de lavas, o soerguimento mais acentuado deste trecho de borda da bacia do Paraná, a superfície de topo posicionada a mais de $1.500 \mathrm{~m}$ de altitude). A densa rede de falhas e fraturas possibilitou, de modo geral, o desenvolvimento de uma densa rede de drenagem com canais fluviais extremamente entalhados e estreitos, sendo comuns os canyons. Em toda esta área, que corresponde ao Planalto Catarinense e Gaúcho e parte do sul do estado do Paraná, as vertentes com altas declividades são descontínuas em forma de degraus e patamares, fornecendo aspecto morfológico bem distinto das formas de relevo encontradas no restante da Bacia Sedimentar do Paraná. Cabe ressaltar que trechos às vezes até bastante extensos de divisores d'água mostram-se menos atacados pela ação fluvial e definem superfícies contínuas com formas de relevo de fraca ondulação, representado por colinas de baixas altitudes. Este tipo de ocorrência é encontrada no Planalto de Guarapuava, PR, Planalto de Campos Novos, Curitibanos, SC, e Planalto de Vacaria, Erechim, RS, correspondendo a superfícies estruturais controladas pelos derrames de rochas ácidas representadas pelos riolitos e os rodacitos.

- As superfícies planas de topo posicionadas no reverso das escarpas de bordas de bacias sedimentares testemunham a interrupção da sedimentação quando do início da epirogênia cenozoica. Estas superfícies, que geralmente se encontram em níveis elevados, quase sempre posicionadas nas bordas das bacias, são conhecidas na literatura como chapadas. Estas bordas arqueadas por epirogênese preservaram-se até os dias atuais dos processos erosivos cincundenudacionais que abriram as depressões que margeiam as bacias sedimentares. Como os arqueamentos cenozoicos resultaram em soerguimentos desiguais ao longo da Plataforma Sul-Americana, as bordas das bacias posicionam-se em níveis altímetricos diferenciados. Assim, no Planalto de Vacaria, RS, a superfície preservada de topo ultrapassa os $1.500 \mathrm{~m}$ próximo à borda (Serra Gaúcha), enquanto os planaltos de Guarapuava, PR, e Campos Novos, SC, estão acima de 1.100 m. Mais ao norte, na região de São Carlos Botucatu, SP, os trechos preservados de topos são menos extensos e pouco mais baixos (800$1.000 \mathrm{~m}$ ) e esculpidos nos arenitos do grupo Bauru. No Planalto de Uberlândia-Araguari, MG, os topos planos e razoavelmente bem preservados encontram-se em torno dos $900 \mathrm{~m}$, fato que se repete na borda oeste e noroeste da bacia onde estão as chapadas dos Guimarães, do alto Taquari e dos Gaúchos (sudoeste de Goiás e Mato Grosso). Estas superfícies preservadas de borda de bacias sedimentares são encontradas, ainda, no Planalto dos Perecis (Chapada dos Parecis, MT), na Chapada da Serra do Divisor ou Chapada do Urucuia nos limites de Goiás e Bahia e nas bordas oeste, sul e sudeste da Bacia do Parnaíba, com ocorrência de chapadas como a das Mangabeiras no estado do Piauí.

- Superfícies Aplanadas por processos erosivos generalizados, embutidas entre bordas de bacias sedimentares e maciços antigos. Estas áreas representam as depressões periféricas claramente definidas por Ab'Saber (1972) e correspondem às grandes formas esculturais do 
relevo brasileiro, cujas gêneses estão associadas aos processos circundenudacionais ocorridos ao longo do Terciário Superior e Quaternário. Estas depressões encontram-se em níveis altimétricos diferenciados, embora tenham idade e gênese comuns. São exemplos clássicos a Depressão Periférica Paulista (550-650 m) e o Segundo Planalto Paranaense (900-1.000 m) e a Depressão Central Sul-rio-grandense (200-300 m). As depressões monoclinais encontradas a oeste e noroeste da Bacia do Paraná (alto rio Taquari e alto rio Vermelho) enquadram-se geneticamente nessa mesma categoria, embora tenham características fisionômicas distintas.

- Superfícies aplanadas antigas sepultadas por sedimentos e posteriormente exumadas, posicionadas nas margens das bordas de bacias sedimentares. Estas superfícies, já definidas por Ab'Saber (1972) como Depressões Marginais com Forte Eversão, correspondem aos terrenos baixos e relativamente aplanados, esculpidos em rochas cristalinas ou em cristalofilianas antigas. São exemplos a Depressão Sertaneja do Nordeste, a Depressão Cuiabana, a Marginal Norte Amazônica, entre outras, menores. Estas superfícies foram esculpidas em ciclos erosivos Pré-Devonianos e sepultadas por espessos pacotes sedimentares pertencentes às bacias sedimentares. Posteriormente, com o arqueamento cenozoico, acompanhado de extensos processos erosivos, foram exumados e reafeiçoados no Cenozoico Superior. Algumas destas depressões, como ocorre com a do alto Paraguai e do Guaporé, receberam mais recentemente extensivos depósitos detríticos Quaternários, tornando-se novamente parcialmente sepultadas.

- Níveis diferenciados de topos nivelados associados a fases de deposição/erosão recentes acondicionados em depressões tectônicas. Estes níveis, que resultam de fases alternadas de deposição e erosão, ocorrem em áreas como a depressão tectônica do médio Vale do Paraíba do Sul (SP), conhecida como Bacia de Taubaté, bem como na Bacia de São Paulo (SP). Nestas duas bacias sedimentares, geradas no Cenozoico Superior, encontram-se os níveis mais elevados definidos pelos topos das colinas esculpidas nos sedimentos terciários, níveis intermediários em formas de colinas e patamares ao longo dos espigões secundários, também gerados pela denudação dos sedimentos e outros associados à gênese mais recente, como ocorre com as planícies e terraços fluviais que margeiam os cursos fluviais principais.

- Níveis diferenciados associados às fases de deposição/erosão quaternárias de ambientes de sedimentação fluvial, marinha e lacustre. Estes níveis, produzidos por alternância de fases deposicionais e erosionais, geram planícies fluviais, marinhas ou lacustres e, quando, por alguma razão, altera-se o nível de base, desenvolve-se um reentalhe dos canais fluviais. Mudanças do nível marinho por regressão geram os terraços marinhos no lugar das planícies.

\section{4 - A GÊNESE DOS NÍVEIS MORFOLÓGICOS NA BACIA DO ALTO PARAGUAI- CUIABÁ}

Os mapeamentos geomorfológicos efetuados na Bacia do alto Paraguai por Ross \& Santos (1982), Ross et alii (1986), Ross (1987) revelaram diversos níveis morfológicos. Alguns dos níveis regionais foram detectados nos mapeamentos regionais nas escalas 1: 1.000 .000 e 1: 500.000 , sendo que outros só se tornaram mais evidentes com os mapeamentos na escala 1: 100.000 .

O trabalho na escala 1: 1000.000 foi produzido na fase de atividade do projeto Radambrasil na região Centro-Oeste, encontrando-se registrado o relatório técnico-científico referente à Folha SD-21 - Cuiabá, publicado em 1982 pelo Ministério das Minas e Energia, juntamente com os demais produtos temáticos como Geologia, Pedologia, Vegetação-Clima e Uso Potencial da Terra. Os trabalhos nas escalas 1: 500.000 e 1: 100.000 foram gerados no 
Laboratório de Geomorfologia do Departamento de Geografia da Faculdade de Filosofia, Letras e Ciências Humanas da Universidade de São Paulo sendo, até o momento ${ }^{2}$, inéditos.

Com estes trabalhos pode-se identificar diversos níveis morfológicos de diferentes gêneses e idades:

1- Topos Planos e Altos das chapadas dos Parecis e Guimarães.

2- Níveis Diferenciados de Topo da Província Serrana.

3- Níveis Diferenciados Intermediários associados aos alinhamentos de cristas de bordas de anticlinais escavados e sinclinais alçadas.

4- Patamar Estrutural do Planalto de Tapirapuã.

5- Superfície do Planalto das bacias dos rios Casca e Quilombo.

6- Superfície de Erosão Antiga coberta por Sedimentos Paleomesozoicos no Planalto da Bacia dos rios Arruda e Mutum.

7- Superfície de Erosão Antiga coberta por Sedimentos Paleomesozoicos com posterior exumação na Depressão Cuiabana.

8- Superfície de Erosão Antiga coberta por Sedimentos Mesozoicos com posterior exumação e sepultamento parcial recente na Depressão do Alto Paraguai.

- As áreas que correspondem aos topos planos e altos da Chapada dos Parecis e da Chapada dos Guimarães encontram-se entre 800-900 m e constituem-se em superfícies extremamente niveladas e muito aplanadas. Estas áreas posicionam-se preferencialmente em trechos de divisor de águas de grandes bacias hidrográficas. A Chapada dos Parecis é o grande divisor de águas entre as bacias dos rios Paraguai, Guaporé e os tributários do rio Amazonas. A Chapada dos Guimarães, embora seja drenada pela alta bacia do rio das Mortes, funciona como grande divisor das bacias dos rios Xingu, Araguaia e Cuiabá.

Estas duas chapadas estão sustentadas principalmente por sedimentos do Cretáceo, pertencentes aos grupos Bauru e Parecis. Recobrem de modo quase que generalizado os topos planos, sedimentos detríticos finos em elevado estágio de pedogenização e com alta concentração de precipitados de ferro. A elevada presença do ferro, nos Latossolos VermelhoEscuros da área, às vezes apresenta-se em forma de bancadas concrecionárias que atingem até dois metros de espessura. Esta cobertura detrítica ferruginizada acaba por determinar no topo das chapadas pequeno patamar com um degrau de 20 a $30 \mathrm{~m}$, que praticamente coroa todo o topo destas.

Existem muitas interpretações a respeito dos topos planos e altos destas chapadas, entretanto o que nos parece mais plausível é que estes testemunham superfícies de sedimentação de idade Cretácea ou, quando muito, do Terciário Inferior. Com o soerguimento Cenozoico, estas áreas foram alçadas aos níveis atuais e preservam-se como relevos residuais, pois encontram-se na posição de divisores das grandes bacias hidrográficas regionais. Esta hipótese já fora levantada por Ross \& Santos (1982) e por Ross (1987) em oposição às interpretações que julgam tais superfícies planas de topo de borda de bacias sedimentares como testemunhos de superfícies de erosão do Terciário e os sedimentos detríticos como correlativos desta fase erosiva.

- Os Níveis Diferenciados de Topo da Província Serrana estão representados pelas cristas mais altas, contínuas e com topos retilinizados posicionados em bordas de anticlinais erodidas e em bordas de sinclinais alçadas, em dorsos amplos e preservados de anticlinais e ainda por trechos planos de topo. Estas características morfológicas são encontradas em pelo menos três níveis topográficos distintos ao longo da Província Serrana, mas todos em posição

\footnotetext{
${ }^{2}$ Artigo publicado em 1991.
} 
de Cimeira. A execução do mapeamento geomorfológico na escala 1:100.000 revelou que a Província Serrana apresenta setores com três níveis de Cimeira bem distintos, embora possam ser interpretados como de gêneses comuns. Um nível de topo aparece entre 500-550 m no setor central da Província Serrana, na região das nascentes do rio Paraguai, posicionado entre as cidades de Diamantino, a oeste, e Nobres, a leste. Neste trecho os topos da Província Serrana mostram-se muito aplanados ou fracamente dissecados e as grandes formas do relevo são concordantes com a estrutura.

Deste modo, os topos estão esculpidos em amplos dorsos de anticlinais preservados ou em anticlinais com os dorsos truncados por erosão, mas com configuração plana em alguns trechos e retilinizados em outros. São exemplos marcantes os topos planos das anticlinais das serras do Requeijão, Vira Saia, Tira Sentido, Bocaina e Tombador.

O nível de topo da Província Serrana que aparece entre 650-700 m é o mais frequente em toda borda oriental da área serrana, quer seja na extremidade norte-nordeste, quer seja no setor sul. Este nível está muito associado às sinclinais alçadas por efeito da tectônica Cenozóica. Tal interpretação encontra apoio no fato de que toda a faixa oriental da Província Serrana é marcada por sinclinais alçadas e estas são delimitadas por falhamentos inversos. Os topos das cristas das bordas destas sinclinais apresentam setores planos e, quando não, cristas niveladas e retilíneas, denotando, em ambos os casos, os efeitos de processos erosivos pretéritos. Há uma predominância de topos planos no setor norte-nordeste na região das altas bacias dos rios Novo, Cuiabá e Teles Pires, como ocorre com as serras de Cuiabá, Azul e Morro Selado. Já nas demais áreas, prevalecem as cristas retilinizadas, niveladas e contínuas das bordas de sinclinais alçadas, representadas por serras como do Retiro, Boi Morto, Chapada, entre outras.

O nível de topo mais elevado da Província Serrana ocorre em trechos mais restritos da área centro-oriental da Província Serrana. Este nível encontra-se entre 800-860 m e está representado tanto por trechos planos e altos como por cristas niveladas, retilinizadas e contínuas de bordas de sinclinais alçadas ou ainda dorsos amplos e preservados de anticlinais. O exemplo mais significativo ocorre com a sinclinal alçada das serras das Araras e Água Limpa, que se apresenta em sua parte central topo plano e nivelado em torno dos $800 \mathrm{~m}$ e as cristas da borda niveladas em torno de $860 \mathrm{~m}$. Esta sinclinal também se encontra ladeada por falhas inversas antigas, reativadas no Cenozoico.

Os três principais níveis de topo da Província Serrana foram interpretados por Ross (1987) como sendo testemunhos de uma única superfície de erosão do Pré-Cretáceo e que foi desmantelada pelo soerguimento desigual de blocos no processo epirogenético Cenozoico.

- Os níveis Diferenciados Intermediários, associados aos alinhamentos de cristas de bordas de anticlinais escavadas e sinclinais alçadas, aparecem em diferentes altitudes. Estes níveis aparecem entre os níveis de topos e a superfície baixa e aplanada que se encontra entre as serras. Correspondem aos alinhamentos de cristas que margeiam as cristas principais e mais elevadas, tanto nas bordas das sinclinais alçadas como no interior das depressões anticlinais. Estas cristas, que se caracterizam ainda por serem de ocorrência descontínua, têm suas gêneses associadas ao caráter estrutural dos dobramentos do Geossinclíneo ParaguaiAraguaia e à presença de litologias de espessura e resistências diferenciadas. A presença de camadas estratificadas de arenitos e calcários oferece graus de resistência diferentes aos processos erosivos. Assim, os diferentes níveis altimétricos destas cristas são decorrentes da erosão diferencial, em face da menor resistência dos calcários, arcóseo, siltitos e de camadas menos espessas de arenito, em frente das camadas espessas e resistentes dos arenitos da Formação Raizama do Grupo Alto Paraguai.

- O Patamar Estrutural do Planalto de Tapirapuã encontra-se no nível dos 450-500 m. É um patamar posicionado entre o topo da Chapada dos Parecis, ao norte, e a Depressão do Alto 
Paraguai, ao sul. Este nível é produto da forte resistência que os derrames de lavas da formação Tapirapuã oferecem ao desgaste erosivo. O Planalto de Tapirapuã está esculpido e sustentado por basaltos. Ao sul, é delimitado por escarpa abrupta, sustentada pelo basalto e, ao norte, por escarpa erosiva esculpida nos arenitos do Parecis. Sua gênese está vinculada ao arranjo estrutural dos derrames do basalto e à erosão diferencial que, ao escavar a Depressão do Alto Paraguai, colocou em ressalto este patamar estrutural.

- A Superfície do Planalto das bacias dos rios Casca e Quilombo encontra-se entre 600700 m e posiciona-se entre o nível de topo da Chapada dos Guimarães e o nível do piso da Depressão Cuiabana. Esta área planáltica localiza-se a noroeste da Chapada dos Guimarães, sendo drenada pelos rios homônimos tributários do rio Manso, principal formador do rio Cuiabá. Este planalto está esculpido em arenitos da Formação Botucatu e do Grupo Bauru. Corresponde a uma área de recuo erosivo que se processou ao longo do Cenozoico Superior, retirando total ou parcialmente a cobertura sedimentar mesozóica e gerando um patamar erosivo pontilhado por alguns morros testemunhos de topos planos e vertentes abruptas. Esta área nivela-se a oeste com a superfície do Planalto das bacias dos rios Arruda e Mutum.

- O Planalto das bacias dos rios Arruda e Mutum, que também se nivela em torno dos $600 \mathrm{~m}$, corresponde a uma Superfície de Erosão antiga coberta por Sedimentos Paleomesozóicos. Com exumações parciais seguidas de novos sepultamentos, esta superfície é de idade Pré-Devoniana. Os metassedimentos do Grupo Cuiabá encontram-se truncados por erosão e sobre este encontram-se depositadas, em discordância erosiva e estratigráfica, rochas do Devoniano (Formações Furnas e Ponta Grossa) e do Mesozoico (Formação Botucatu e Grupo Bauru). O Planalto das bacias dos rios Arruda e Mutum é, portanto, testemunho de fases erosivas que ocorreram no Pré-Devoniano, no Mesozoico e no Cenozoico, quando as coberturas sedimentares do Grupo Bauru foram erodidas exumando-se, assim, mais uma vez a superfície nivelada nos $600 \mathrm{~m}$ deste planalto.

- A Superfície de Erosão Antiga, coberta por Sedimentares Paleomesozoicos, com posterior exumação na Depressão Cuiabana, tem gênese semelhante ao Planalto das bacias dos rios Arruda e Mutum. A diferença, entretanto, é que esta depressão passou por um rebaixamento mais extensivo. O desgaste erosivo esculpiu uma superfície bastante aplanada e inclinada para o norte. Deste modo, enquanto na parte sul as altimetrias oscilam em torno dos $150 \mathrm{~m}$, gradativamente ganha altitude para o norte e chega a 400-450 m no alto dos rios Manso e Cuiabá. Não há testemunho residual que possa comprovar a presença anterior de coberturas paleomesozóicas sobre a atual superfície. Entretanto, toda sua porção leste e nordeste é delimitada por escarpas alcantiladas sustentadas pelas rochas Pré-Cambrianas do Grupo Cuiabá (Na base da escarpa) e Paleomesozóicas - Furnas - Ponta Grossa - Bauru (Na escarpa da altura média à superior). $\mathrm{O}$ piso desta é esculpido nos metassedimentos do Grupo Cuiabá, visivelmente truncados pelos processos erosivos que em diferentes momentos atuaram na área. Ao sul, abaixo dos $150 \mathrm{~m}$, a depressão cede lugar aos sedimentos do Pantanal Mato-Grossense de origem recente, sob efeito das águas fluviais e pluviais.

- A Superfície de Erosão Antiga coberta por Sedimentos Mesozoicos, com posterior exumação e inumação parcial recente na Depressão do Alto Paraguai, tem também história semelhante à da Depressão Cuiabana. No entanto, esta depressão aplanada é praticamente horizontalizada, ao contrário daquela que, conforme já foi dito, é inclinada. Parece-nos bastante provável que a Depressão do Alto Paraguai, de fato, após passar por fases erosivas antigas, fora encoberta por sedimentação mesozoica e no Cenozoico foi exumada pelos processos erosivos circundenudacionais. Isto se pode conjecturar em face da presença, ao norte e noroeste, das escarpas mantidas por basaltos (Formação Tapirapuã) e arenitos (Grupo Parecis) e que delimitam esta unidade do relevo. A depressão passou, a seguir, por uma fase de recobrimento por sedimentos do Quaternário da Formação Pantanal que se estende por 
grande parte da área. É necessário ressaltar que tais sedimentos encontram-se neste trecho da depressão em fase de denudação com reentalhamento incipiente da drenagem.

\section{5 - CONSIDERAÇÕES FINAIS}

Este trabalho, que procura sintetizar resultados de estudos anteriores, tem como objetivo recolocar velhas questões em discussão. Isto é perfeitamente válido à medida que os estudos efetuados por De Martonne, King, Bigarella, Ab'Sáber entre inúmeros outros, não dispunham de mapeamentos sistemáticos de geologia e geomorfologia e às vezes nem sequer haviam cartas topográficas em escalas compatíveis para boas análises. Por outro lado, há que considerar ainda que, à exceção de Ab'Sáber, os demais pesquisadores sempre desenvolveram trabalhos regionais ou locais, não dispondo de um adequado entendimento do que ocorria no restante do território nacional.

$\mathrm{O}$ ato de coragem em produzir um documento-síntese como o que aqui se apresenta, apoia-se em vários fatos de naturezas diversas, que possibilitam generalizar uma análise sintética a respeito das formas do relevo brasileiro e sua gênese. Entre os fatos de maior significância, estão:

- Existir um mapeamento geológico e geomorfológico sistemático para todo o país, produzido pelo projeto Radambrasil.

- Dispor-se atualmente de excelentes instrumentos de pesquisa, como as imagens de radar e de satélite, que oferecem informações mais próximas da verdade.

- A existência de inúmeros trabalhos geológicos e geomorfológicos locais e regionais que, correlacionados entre si, possibilitam maior acerto nas análises.

- Evolução das técnicas de interpretação, avanços metodológicos e novas teorias que permitiram melhor clarear o entendimento da evolução geológica e geomorfológica.

- A participação efetiva do autor deste trabalho em pesquisas e mapeamentos sistemáticos de geomorfologia em grande parte do território nacional; Os treinamentos experimentais no Laboratório de Geomorfologia da Universidade de São Paulo, com alunos estagiários de graduação e pós-graduação e inúmeras expedições de campo por quase todo o País.

Cabe ressaltar, entretanto, que as interpretações aqui sintetizadas, embora estejam calcadas nos fatos enumerados, são passíveis de questionamentos. Não se tem a pretensão de fechar a discussão sobre os eventos aqui descritos e interpretados, pelo contrário, a intenção é retomar velhas questões e rediscuti-las sob a luz dos novos conhecimentos; só assim é possível fazer o conhecimento científico fortalecer-se.

Os futuros leitores deste trabalho também poderão estranhar, e até mesmo questionar, o fato de que se deu uma forte valorização às interferências estruturais, litológicas e tectônicas no processo gerador das formas e não se discutiu, em nenhum momento, os climas e paleoclimas que esculpiram as atuais formas do relevo. Isto, entretanto, não significa que a variável clima tenha sido esquecida, apenas não foi dada ênfase a ela. A variável climática, que em última análise é responsável pela erosão e, portanto, pela esculturação das formas estruturais, foi genericamente tratada por processos erosivos, erosão circundenudacional, denudação, sem que se entre nos pormenores dos processos operantes no passado e no presente.

Este procedimento deu-se propositadamente por vários motivos, destacando-se os que serão discutidos a seguir: 
- Acreditamos, baseados nos mapeamentos sistemáticos e nas pesquisas de campo, que as variáveis estruturais (Litologia, arranjo estrutural, tectônica) são de maior peso na determinação das formas maiores do relevo. Deste modo, os processos endogenéticos são, sem dúvida, os criadores das primeiras formas do relevo. Não se pode afirmar que, no estudo da gênese das formas do relevo terrestre, a estrutura responde apenas por uma certa ossatura do modelado.

- A ação climática que comanda os processos exogenéticos, de fato, exerce papel importante na esculturação, na modelagem das formas estruturais originalmente criadas. As atuações climáticas precisam ser extremamente prolongadas (milhões de anos) para anular ou, senão, para diminuir a influência estrutural nas formas grandes do relevo. Assim, quando se tomam exemplos de superfícies de erosões planas cortando estruturas rochosas cristalinas ou cristalofilianas, como ocorre com alguns trechos do relevo brasileiro, só se pode atribuir isso a processos erosivos muito antigos, prolongados e extensivos e que por alguma razão se preservam parcialmente até os dias atuais.

Procurou-se não entrar nas discussões dos climas e paleoclimas úmidos e quentes, árido semiáridos, ou até mesmo os glaciais, responsáveis pela esculturação das formas do relevo, por ser de fato já bastante conhecidos e discutido por diversos pesquisadores, não havendo nada a acrescentar ou questionar. Além disso, acreditamos que os tipos climáticos que aqui atuaram no passado não deixaram bons testemunhos que nos permitam afirmar com segurança que uma determinada forma de relevo, quer seja ela grande ou pequena, fora produzida por clima árido, glacial ou úmido. Isto se deve ao fato de que os ambientes tropicais úmidos tendem a eliminar estes testemunhos através da intensa meteorização e pedogenização.

\section{REFERÊNCIAS}

AB'SABER, A. N. Da participação das Depressões Periféricas e Superfícies Aplainadas compartimentação do Planalto Brasileiro. Geomorfologia 28, IGCOG/USP, São Paulo, 1972.

AB'SÁBER, A. N. O relevo brasileiro e seus problemas. Brasil, a Terra e o Homem, v. 1, Cap. III, Cia. Editora Nacional, São Paulo, 1964.

AB'SÁBER, A. N. Posição das Superfícies Aplainadas no Planalto Brasileiro. Notícias Geomorfológicas 5, Campinas, 1960.

AB’SÁBER, A. N. Províncias Geológicas e Domínios Morfoclimáticos no Brasil.

Geomorfologia 20, IGEOG/USP, São Paulo, 1969.

AB'SÁBER, A. N. Regiões de Circundenudação Pós-Cretáceos no Planalto Brasileiro. Boletim Paulista de Geografia 1, São Paulo, 1949.

AB'SÁBER, A. N. Ritmo de Epirogênese Pós-Cretácica e setores das superfícies Neogênicas em São Paulo. Geomorfologia 13, IGEOG/USP, São Paulo, 1969.

AB'SÁBER, A. N. Domínios Morfoclimáticos Atuais e Quaternários a região de Cerrados. Cráton e Intracráton 14, IBELCE/UNESP, São José do Rio Preto, 1981.

AB'SÁBER, A. N. Espaços ocupados pela expansão dos climas na américa do Sul por ocasião dos Períodos Glaciais Quaternários, Paleoclima 3, IGEOG/USP, São Paulo, 1977. 
AB'SÁBER, A. N. A organização natural das paisagens inter e subtropicais brasileiras. Geomorfologia 41, IGEOG/USP, São Paulo, 1973.

ALMEIDA, F. F. M. de. Geologia do Centro-Oeste Mato-Grossense. DNPM, v. 1215, Rio de Janeiro, 1964.

ALMEIDA, F. F. M. de. Origem e evolução da Plataforma Brasileira. DNPM, Depto. De Geologia e Mineralogia 214, Rio de Janeiro, 1967.

ALMEIDA, F. F. M. de. Geossinclíneo Paraguaio. Anais do XXVII Congresso da Sociedade Brasileira de Geologia, Porto Alegre, 1974.

ALMEIDA, F. F. M. de. Sistema Marginal do Cráton do Guaporé. Congresso Brasileiro de Geologia 28, 1974, Anais da Sociedade Brasileira de Geologia, Porto Alegre, 1974.

ALMEIDA, F. F. M. de; HENNIES, W.T. Novos conhecimentos sobre o Geossinclíneo Paraguaio. Avulso da Divisão de Geologia e Mineralogia, Rio de Janeiro, 1965.

ALVARENGA, S. M.; BRASIL, A. C.; DEL'ARCO, P. M. Geomorfologia da Folha SF 21 - Campo Grande, Série Levantamento dos Recursos Naturais, Projeto Radambrasil, v. 28, Rio de Janeiro, 1982.

BARBOSA, G. V.; BOAVENTURA, R. S.; PINTO, M. N. Geomorfologia da Folha SB 23 Terezina e parte da folha SB 24 - Jagaribe, Série Levantamento dos Recursos Naturais, M.M.E., Projeto Radambrasil, v.2, Rio de Janeiro, 1973.

BARBOSA, G. V.; RENNÉ, C. V.; FRANCO, E. M. S. Geomorfologia da Folha SA 22 Belém, Série Levantamento dos Recursos Naturais, M.M.E., Projeto Radambrasil, v. 5, Rio de Janeiro, 1974.

BIGARELLA, J. J.; MOUSINHO, M. R.; SILVA, J. X. Pediplanos, Pedimentos e seus Depósitos Correlativos no Brasil. Boletim Paranaense de Geografia, 16 e 17, Curitiba, 1965.

BOAVENTURA, R. S. Geomorfologia da Folha SB 22 - Araguaia e parte da Folha SC 22 - Tocantins, Série Levantamento dos Recursos Naturais, M.M.E., Projeto Radambrasil, v. 4, Rio de Janeiro, 1974.

BRAUN, O. P. G. Contribuição à Geomorfologia do Brasil Oriental. Revista Brasileira de Geografia 3, Rio de Janeiro, 1971.

DE MARTONNE, E. Problemas morfológicos do Brasil Tropical Atlântico. Revista Brasileira de Geografia 4, ano V, IBGE, Rio de Janeiro, 1943.

FRANCO, E. M. S.; MOREIRA, M. M. M. A. Geomorfologia da Folha SA 19 - Iça, Série Levantamento dos Recursos Naturais, M.M.E., Projeto Radambrasil, v. 14, Rio de Janeiro, 1977. 
FRANCO, E. M. S.; DEL'ARCO, J. O.; RIVETTI, M. Geomorfologia da Folha NA 20 Boa Vista e parte das Folhas NA 21 - Tumucumaque e NB 20 - Roraima e NB 21, Série Levantamento dos Recursos Naturais, M.M.E., Projeto Radambrasil, v. 8, Rio de Janeiro, 1975.

FRANCO, M. S. M.; PINHEIRO, R. Geomorfologia da Folha SE 21 - Corumbá e parte da Folha SE 20, Série Levantamento dos Recursos Naturais, M.M.E., Projeto Radambrasil, v. 27, Rio de Janeiro, 1982.

GATTO, L. C. S. et alii. Geomorfologia das Folhas SF 23/24 - Rio de Janeiro/ Vitória, Série Levantamento dos Recursos Naturais, M.M.E., Projeto Radambrasil, v. 32, Rio de Janeiro, 1983.

JUSTUS, J. O.; MACHADO, M. L. A.; FRANCO, M. S. M. Geomorfologia da Folha SH 22 - Porto Alegre e parte das Folhas SH 21 - Uruguaiana e SI 22 - Lagoa Mirim, Série Levantamento dos Recursos Naturais, Secretaria do Planejamento da Presidência da República, FIBGE, v. 33, Rio de Janeiro, 1986.

KING, L. C. A Geomorfologia do Brasil Oriental. Revista Brasileira de Geografia 18, Rio de Janeiro, 1956.

KUX, H. J. H.; BRASIL, A. E.; FRANCO, M. S. M. Geomorfologia da Folha SP 20 Guaporé, Série Levantamento dos Recursos Naturais, M.M.E., Projeto Radambrasil, v. 19, Rio de Janeiro, 1979.

LUZ, J. S. et alii. Projeto Província Serrana, Relatório Final DNPM/CPRM, Goiânia, 1978.

MAMEDE, L.; NASCIMENTO, M. A. L. S. do; FRANCO, M. S. M. Geomorfologia da Folha SO 22 - Goiás, Série Levantamento dos Recursos Naturais, M.M.E., Projeto Radambrasil, v. 25, Rio de Janeiro, 1981.

MAMEDE, L.; ROSS, J. L. S.; SANTOS, L. M. dos. Geomorfologia da Folha SC 22 Tocantins, Série Levantamento dos Recursos Naturais, M.M.E., Projeto Radambrasil, v. 22, Rio de Janeiro, 1981.

MAMEDE, L.; ROSS, J. L. S.; SANTOS, L. M. dos; NASCIMENTO, M. A. L. do. Geomorfologia da Folha SE 22 - Goiânia, Série Levantamento dos Recursos Naturais, M.M.E., Projeto Radambrasil, v. 31, Rio de Janeiro, 1983.

MAURO, C. A. de; DANTAS, M.; ROSO, F. A. A Geomorfologia da Folha SD 23 Brasília, Série Levantamento dos Recursos Naturais, M.M.E., Projeto Radambrasil, v. 29, Rio de Janeiro, 1982.

MELLO, D. P. de; PITTHAN, J. M. L.; ALMEIDA, V. J. Geomorfologia da Folha SC 19 Rio Branco, Série Levantamento dos Recursos Naturais, M.M.E., Projeto Radambrasil, v. 12, Rio de Janeiro, 1976. 
MELLO, D. P. de; COSTA, R. C. R. da; NATALI FILHO, T. Geomorfologia da Folha SC 20 - Porto Velho, Série Levantamento dos Recursos Naturais, M.M.E., Projeto Radambrasil, v. 16, Rio de Janeiro, 1978.

MERCERJAKOV, J. P. Les Concepts de Morphoestruture et de Morphoesculture: un nouvel instrument de I' analyse géomorphologique. Annales de Geographie 423, 1968.

MOREIRA, M. M. M. A.; GATTO, L. C. S. Geomorfologia da Folha SA 24 - Fortaleza, Série Levantamento dos Recursos Naturais, M.M.E., Projeto Radambrasil, v. 21, Rio de Janeiro, 1981.

NASCIMENTO, D. A. do; PRATES, M. Geomorfologia da Folha SA 21 - Santarém, Série Levantamento dos Recursos Naturais, M.M.E., Projeto Radambrasil, v. 10, Rio de Janeiro, 1976.

NOU, E. A. V.; BEZERRA, L. M. M.; DANTAS, M. Geomorfologia das Folhas SC 24/25 Aracaju/Recife, Série Levantamento dos Recursos Naturais, M.M.E., Projeto Radambrasil, v. 30, Rio de Janeiro, 1983.

PINTO, M. N. Superfícies de Aplainamento do Distrito Federal. Revista Brasileira de Geografia 2, ano 49, IBGE, Rio de Janeiro, 1987.

PRATES, M.; GATTO, L. C. S.; COSTA, J. I. P. Geomorfologia das Folhas SC 24/25 Jaguaribe/Natal, Série Levantamento dos Recursos Naturais, M.M.E., Projeto Radambrasil, v. 23, Rio de Janeiro, 1981.

ROSS, J. L. S.; SANTOS, L. M. dos. Geomorfologia da Folha SD 21 - Cuiabá, Série Levantamento dos Recursos Naturais, M.M.E., Projeto Radambrasil, v. 26, Rio de Janeiro, 1982.

ROSS, J. L. S. As Unidades Morfoesculturais: uma nova classificação do relevo brasileiro. III Simpósio de Geografia Física Aplicada, v. 1, Nova Friburgo (RJ), 1989.

ROSS, J. L. S. Relevo Brasileiro: uma nova proposta de classificação. Revista do Departamento de Geografia, FFLCH/USP, São Paulo, 1985.

ROSS, J. L. S. Estudo e cartografia geomorfológica da Província Serrana - MT, Tese de Doutorado apresentada à FFLCH/USP, São Paulo, 1987.

RUELLAN, F. O Escudo Brasileiro e os Dobramentos de Fundo. Faculdade Nacional de Filosofia, Departamento de Geografia, Universidade do Brasil, Rio de Janeiro, 1952.

VENTURA, L. M.; D’AVILA, L. M.; BARBOSA, G. V. Geomorfologia da Folha SB 21 Tapajós, Série Levantamento dos Recursos Naturais, M.M.E., Projeto Radambrasil, v. 7, Rio de Janeiro, 1975. 